\title{
KEBIJAKAN KELAUTAN INDONESIA DALAM PERSPEKTIF UNCLOS 1982
}

\author{
Peni Susetyorini \\ Fakultas Hukum Universitas Diponegoro Semarang \\ J1. Prof. Sudarto SH Tembalang Semarang \\ penifhundip@yahoo.co.id
}

\begin{abstract}
Indonesia is the largest archipelagic country in the world, with strategic geographical conditions and rich in natural resources, but all of them still cannot be utilized optimally for the nation's prosperity. Many factors cause this, ranging from the paradigm of development errors to the chaotic maritime law enforcement efforts. Constraints in fulfilling adequate infrastructure in maritime affairs are the main obstacle that must be resolved by the government, because the existence of infrastructure will enable better service. The issue of reforming the law enforcement system through strengthening and coordination between the competent institutions in the sea will greatly support the creation of law enforcement harmony, so maritime actors will get certainty to whom they should depend on their hopes if they get into trouble at sea. This research aims to analyze the rights and obligations of the state in implementing the Convention on the Law of the Sea (Unclos) 1982 which has been ratified by the Indonesian state with Act Number 17 of 1985 concerning the Ratification of the United Nations Convention on The Law of the Sea, and analyze Indonesian marine policy in an effort to realize the Indonesian state as the world's maritime axis.
\end{abstract}

Keywords: State Rights and Obligations; Maritime Axis; Convention on the Law of the Sea (Unclos) 1982

\begin{abstract}
Abstrak
Indonesia sebagai negara kepulauan terbesar di dunia, dengan kondisi geografis yang strategis dan kaya akan sumberdaya alam, namun semuanya masih belum dapat dimanfaatkan secara optimal demi kemakmuran bangsa. Banyak faktor yang menyebabkan hal tersebut, mulai dari kesalahan paradigma pembangunan hingga carut marutnya upaya penegakan hukum kemaritiman. Kendala pemenuhan intrastruktur yang memadai dalam kemaritiman merupakan kendala utama yang harus diselesaikan pemerintah, karena keberadaan infrastruktur akan memungkinkan pelayanan yang lebih baik. Persoalan pembenahan sistem penegakan hukum melalui penguatan dan koordinasi antar lembaga yang berwenang di laut akan sangat menunjang bagi terciptanya keselarasan penegakan hukum, sehingga para pelaku kemaritiman akan mendapatkan kepastian kepada siapa mereka harus menggantungkan harapannya bila mereka mendapatkan kesulitan di laut. Penelitian ini bertujuan menganalisis hak dan kewajiban negara dalam mengimplementasikan Konvensi Hukum Laut (Unclos) 1982 yang telah diratifikasi oleh negara Indonesia dengan Undang-Undang Nomor 17 Tahun 1985 tentang Pengesahan United Nation Convention on The Law of The Sea, dan menganalisis kebijakan kelautan Indonesia dalam upaya mewujudkan negara Indonesia sebagai poros maritim dunia.
\end{abstract}

Kata kunci: Hak dan Kewajiban Negara; Poros Maritim; Konvensi Hukum Laut (Unclos) 1982 


\section{A. Pendahuluan \\ 1. Latar Belakang}

Semenjak berakhirnya Perang Dunia II, tidak ada cabang hukum Internasional yang lebih banyak mengalami perubahan secara mendalam dan revolusioner, selain hukum laut. Hukum laut telah mengalami perubahanperubahan yang mendalam sesuai dengan perkembangan zaman. Hal ini dikarenakan sumber kekayaan mineral yang terkandung di dasar laut itu sendiri, merupakan penghubung bangsa-bangsa dari segala sektor kegiatan manusia, dan kekayaan sumber hayati serta $70 \%$ dari permukaan bumi terdiri dari laut (Boer Mauna, 2005). Secara geografis Indonesia merupakan negara maritim, yang memiliki luas laut sebesar 5,8 Juta $\mathrm{km}^{2}$ yang terdiri dari laut territorial dengan luas 0,8 juta $\mathrm{Km}^{2}$, laut nusantara 2,3 juta $\mathrm{Km}^{2}$ dan zona ekonomi eksklusif 2,7 juta $\mathrm{Km}^{2}$. Indonesia juga memiliki pulau sebanyak 17.480 pulau dan garis pantai sepanjang $95.181 \mathrm{Km}^{2}$ (Boer Mauna, n.d.).

Indonesia sebagai negara kepulauan, telah diakui secara internasional berdasarkan United Nations Convention on the Law of the Sea (UNCLOS) 1982 yang kemudian diratifikasi oleh Indonesia dengan UndangUndang No.17 Tahun 1985 tentang Pengesahan United Nation Convention on The Law of The Sea. Kebijakan kelautan negara Indonesia lebih lanjut telah dituangkan dalam Peraturan Presiden Nomor 16 Tahun 2017 tentang Kebijakan Kelautan Indonesia. Pembangunan bidang kelautan dan perikanan hingga saat ini masih jauh dari harapan, padahal wilayah pesisir dan pulau-pulau kecil dan lautan kepulauan Indonesia memiliki potensi sumber daya alam dan jasa lingkungan yang sangat besar dan belum dimanfaatkan secara optimal.

Indonesia sebagai negara kepulauan (archipelagic state) sudah lama diperjuangkan di forum internasional. Diawali dengan Deklarasi Djuanda tahun 1957, lalu diikuti UU / Prp No 4 Tahun 1960 tentang Perairan
Indonesia. Indonesia menawarkan konsep "Negara Kepulauan" untuk dapat diterima di Konferensi Hukum Laut Perseriktan BangsaBangsa (PBB) III, sehingga dalam The United Nations Convention on the Law of the Sea (UNCLOS) 1982 dicantumkan dalam Bagian IV mengenai Negara Kepulauan. Konsepsi itu menyatukan wilayah Indonesia, sehingga di antara pulau-pulau Indonesia tidak ada laut bebas, karena sebagai negara kepulauan, Indonesia boleh menarik garis pangkal (baselines-nya) dari titik-titik terluar pulaupulau terluar (the outermost points of the outermost islands and drying reefs). Hal itu ditegaskan dalam UU No 6 Tahun 1996 tentang Perairan Indonesia sebagai pengganti UU/Prp No 4 Tahun 1960 sebagai wujud diimplementasikannya UNCLOS 1982 dalam hukum nasional kita(Melda Kamil Ariadno, 2018).

Secara kelembagaan dan hukum, pada tahun 2014 muncul dua momentum pembangunan kelautan yakni, terbitnya Undang-Undang Nomor 32 Tahun 2014 tentang Kelautan, serta pembentukan Kementerian Koordinator Maritim yang memperkuat dan mempertegas landasan hukum dan tata kelola pembangunan kelautan nasional. Selanjutnya pada tahun 2017 telah dikeluarkan Peraturan Presiden (Perpres) Nomor 16 Tahun 2017 tentang Kebijakan Kelautan Indonesia.

UNCLOS 1982 membawa konsekuensi logis bagi bangsa Indonesia yaitu adanya amanat yang harus dilaksanakan berupa hakhak dan kewajiban dalam pengelolaan wilayah kelautan Indonesia berdasarkan hukum internasional. UNCLOS 1982 kini telah berjalan selama 36 tahun, tentu sebagai Negara Kepulauan sudah saatnya melakukan evaluasi kebijakan tentang apa saja yang telah dilaksanakan dan belum dilaksanakan dalam rangka memenuhi amanat seperti yang telah dicantumkan dalam UNCLOS 1982. Permasalahan yang diketengahkan dalam penelitian ini adalah : 
a. Bagaimana Kebijakan Kelautan Indonesia dikaitkan dengan hak dan kewajiban negara berdasarkan UNCLOS 1982 ?

b. Bagaimana Indonesia dapat mewujudkan konsep poros maritim dunia sesuai ketentuan UNCLOS 1982 ?

\section{Metode Penelitian}

Penelitian hukum doktrinal ini menggunakan data sekunder, yang metode pengumpulan data dilakukan dengan cara studi pustaka (bibliography study), studi dokumen (document study), dan studi arsip (file of record study). Dogmatik hukum dimaksudkan mengenai interpretasi hukum positif tentang hak dan kewajiban Negara Indonesia terkait dengan telah diratifikasinya Unclos 1982. Analisis dilakukan secara kualitatif dengan pola berfikir deduktif yakni proses analisa yang berangkat dari misi dan gaya pemikiran yang sifatnya umum atau pola berfikir yang diambil berdasarkan data umum untuk kemudian diaplikasikan kepada kesimpulan yang bersifat khusus setelah terlebih dahulu dilakukan kategorisasi.(Hadi, 1980) Pengolahan data dimulai dengan editing, klasifikasi, verifikasi, analisis, dan konklusi.

\section{Kerangka Konseptual}

James E Anderson menyatakan bahwa kebijakan adalah "...a purposive course of action followed by an actor or set of actors in dealing with a problem or matter of concern" (Serangkaian tindakan yang mempunyai tujuan tertentu yang diikuti dan dilaksanakan oleh seorang pelaku atau sekelompok pelaku guna memecahkan suatu masalah tertentu). Konsep kebijakan yang ditawarkan oleh Anderson ini menurut Budi Winarno(Winarno, 2007), dianggap lebih tepat karena pada apa yang sebenarnya dilakukan dan bukan pada apa yang diusulkan atau dimaksudkan. Selain itu konsep ini juga membedakan secara tegas antara kebijakan (policy) dengan keputusan (decision) yang mengandung arti pemilihan diantara berbagai alternatif yang ada. Implementasi kebijakan bukanlah sekedar bersangkut paut dengan mekanisme penjabaran keputusan politik ke dalam prosedur rutin lewat birokrasi, tetapi lebih dari itu menyangkut masalah konflik, keputusan, dan siapa memperoleh apa dari suatu kebijakan.(Wahab, 2005)

Rezim pembangunan kelautan nasional setidaknya menunjukkan enam peraturan perundang-undangan yang menjadi payung hukum utama dalam pelaksanaannya. Peraturan tersebut adalah: (1) UndangUndang Nomor 5 Tahun 1983 tentang Zona Ekonomi Eksklusif (ZEE) Indonesia; (2) Undang- Undang Nomor 17 Tahun 1985 tentang Pengesahan UNCLOS; (3) UndangUndang Nomor 6 Tahun 1996 tentang Perairan Indonesia; (4) Undang-Undang Nomor 31 Tahun 2004 yang diubah dengan UU. No 5 Tahun 2009 tentang Perikanan; (5) Undang-Undang Nomor 27 Tahun 2007 yang diubah dengan UU No. 1 Tahun 2014 tentang Pengelolaan Pesisir dan Pulau-Pulau Kecil; serta (6) Undang-Undang Nomor 32 Tahun 2014 tentang Kelautan.

Suatu kebijakan apapun sebenarnya mengandung resiko untuk gagal (policy failure). Kegagalan kebijakan dalam dua kategori, yaitu kebijakan yang tidak terimple-mentasikan (non-implementation), dan implementasi yang tidak berhasil (unsuccessful implementation) (Brian W. Hogwood; Lewis. A. Gun, 1984). Non implementation terjadi karena pihak yang terlibat dalam pelaksanaannya tidak mau bekerja sama atau telah bekerja sama secara tidak efisien, bekerja setengah hati atau karena tidak sepenuhnya menguasai permasalahan, atau permasalahan yang diselesaikan diluar jangkauan kekuasaann.

Kebijakan kelautan (termasuk poros maritim yang menjadi bagian dari poros maritim dunia) menunjukkan adanya pilihan antara kebijakan domestik dengan kebijakan internasional. Pilihan internasional dan domestik dalam kebijakan tersebut menunjukkan adanya intermestik (Kawilarang, n.d.). Intermestik merupakan akronim dari internasional-domestik yang 
biasanya digunakan dalam konteks yang berhubungan dengan atau mengenai permasalahan dalam negeri (domestik) serta menyangkut antarbangsa (internasional).

Pendekatan intermestik bertujuan untuk menganalisis proses perubahan di era globalisasi tanpa batas seperti saat ini, dimana sangat sulit membedakan antara kebijakan yang dipengaruhi politik internasional dan kebijakan yang dipengaruhi politik domestik, sebab keduanya saling berkaitan. Pendekatan intermestik yang menjadi jembatan antara pendekatan internasional dan pendekatan faktor domestik/pemerintah dibentuk dari hasil sintesis kajian sebelumnya yang juga bertujuan merumuskan proses keterkaitan pengaruh internasional dan domestik terhadap perubahan kebijakan.(Kurniawati, n.d.)

Negara-negara yang berbatasan dengan laut, termasuk Indonesia memiliki kedaulatan penuh atas wilayah perairan pedalaman, perairan kepulauan dan laut territorial, sedangkan untuk zona tambahan, zona ekonomi eksklusif dan landas kontinen, negara memiliki hak-hak eksklusif, misalnya hak memanfaatkan sumberdaya alam yang ada di zona tersebut. Sebaliknya, laut lepas merupakan zona yang tidak dapat dimiliki oleh negara manapun, sedangkan kawasan dasar laut internasional dijadikan sebagai bagian warisan umat manusia. Berdasarkan uraian di atas, maka kerangka konseptual kebijakan kelautan Indonesia terkait hak dan kewajiban negara sebagai upaya mewujudkan poros maritim dunia dalam rangka melaksanakan Unclos 1982 dapat digambarkan sebagai berikut :

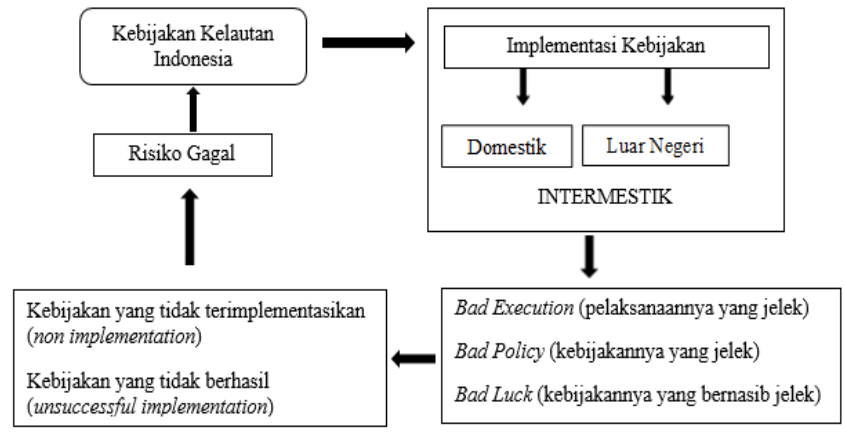

B. Hasil dan Pembahasan

1. Kebijakan Kelautan Indonesia Dikaitkan Dengan Hak dan Kewajiban Negara Berdasarkan UNCLOS 1982. Konvensi PBB tentang Hukum Laut (UNCLOS) 1982 melahirkan delapan zonasi pengaturan (regime) hukum laut yaitu :

1). Perairan Pedalaman (Internal Waters).

2). Perairan Kepulauan (Archiplegic Waters), termasuk di dalamnya selat yang digunakan untuk pelayaran internasional.

3). Laut Teritorial (Teritorial Waters).

4). Zona Tambahan (Contingous Waters).

5). Zona Ekonomi Eksklusif (Exclusif Economic Zone).

6). Landas Kontinen (Continental Shelf).

7). Laut Lepas (High Seas).

8). Kawasan Dasar Laut Internasional (International Sea-Bed Area).

Perairan pedalaman (internal waters) adalah bagian dari perairan suatu negara yang tunduk pada kedaulatan negara tersebut, seperti halnya perairan pedalaman di Indonesia yang sudah diatur oleh UndangUndang Nomor 6 Tahun 1996 tentang Perairan Indonesia.

Hak dan Kewajiban Indonesia serta Status saat ini terhadap perairan pedalaman Indonesia sepenuhnya berada di bawah kedaulatan Negara Indonesia. Indonesia saat ini belum menetapkan wilayah perairan pedalaman dengan identifikasinya. Selain itu di perairan pedalaman terdapat pelabuhan tempat bongkar muat barang ekspor-impor dari dan ke Indonesia. Dalam konteks pembangunan ekonomi nasional Indonesia, 
pelabuhan-pelabuhan yang ada di Indonesia sudah seharusnya mempunyai standar internasional dan mampu bersaing secara global dengan pelabuhan-pelabuhan luar negeri. Indonesia wajib memberikan keamanan dan keselamatan pelayaran internasional sejalan dengan International Ship and Port Facility Security (ISPS) Code yang diadopsi oleh International Maritime Organization (IMO) tanggal 12 Desember 2002.

Perairan pedalaman Indonesia sering dijadikan tempat pembuangan limbah sehingga perairan pedalaman di beberapa tempat di Indonesia sering tampak kotor, dan mungkin terjadi pencemaran lingkungan laut dan perusakan habitatnya. Apabila pemerintah membiarkan keadaan tersebut di perairan pedalaman, maka dapat dianggap telah melanggar kewajiban negara untuk melindungi dan melestarikan lingkungan laut sebagaimana ditegaskan oleh Pasal 192 Konvensi Hukum Laut 1982 yang berbunyi : "States have the obligation to protect and preserve the marine environment". Kewajiban Indonesia di perairan pedalaman adalah untuk kepentingan Indonesia, yaitu berupa kewajiban menjaga dan melestarikan lingkungan hidup secara keseluruhan.

Perairan kepulauan (Archiplegic Waters), Indonesia sebagai negara kepulauan lebih banyak mempunyai hak daripada kewajiban menurut Konvensi Hukum Laut (Unclos) 1982. Hak tersebut seperti menetapkan garis pangkal lurus kepulauan sehingga menjadi bagian kedaulatan RI. Perairan kepulauan (Archiplegic Waters) yang semula dulu adalah bagian dari laut lepas, sekarang menjadi bagian dari kedaulatan Indonesia, sehingga Indonesia harus benar-benar memanfaatkan kekayaan sumber daya alam di laut tersebut. Hak dan Kewajiban Indonesia serta Status saat ini terhadap perairan kepulauan, Indonesia harus menghormati perjanjianperjanjian dengan negara tetangga yang sudah ada sebelumnya, menghormati hak penangkapan ikan tradisional yang dilakukan oleh negara tetangga, sebagaimana tertuang dalam Undang-Undang No. 1 Tahun 1983 Tentang Pengesahan Perjanjian antara RI Malaysia Tentang Rezim Hukum Negara Nusantara dan Hak-hak negara Malaysia di laut teritorial dan perairan nusantara serta ruang udara di atas laut teritorial perairan nusantara dan wilayah RI yg terletak diantara Malaysia Timur dan Malaysia Barat.

Laut Teritorial (Teritorial Waters) telah diatur oleh Konvensi, yaitu yang terdapat dalam Bab II Konvensi Hukum Laut 1982 berjudul "Territorial Sea and Contiguous Zone" dari mulai Pasal 2 s/d Pasal 32. Hak dan Kewajiban Indonesia serta Status saat ini terhadap laut territorial, Indonesia berdaulat penuh di laut teritorial, tetapi apabila laut teritorial Indonesia berhadapan atau berdampingan dengan negara tetangga, maka harus ditetapkan batas-batas laut teritorial tersebut dengan negara itu sebagaimana diwajibkan oleh Pasal 15 Konvensi Hukum Laut (Unclos)1982. Ketentuan Pasal 2 s/d Pasal 32 Konvensi Hukum Laut 1982 tersebut sudah implementing legislation, yaitu dengan Undang-Undang Nomor 6 Tahun 1996 tentang Perairan Indonesia dan aturan pelaksanaannya, yakni Peraturan Pemerintah Nomor 36 Tahun 2002 tentang Hak dan Kewajiban Kapal Asing dalam Melaksanakan Lintas Damai melalui Perairan Indonesia, Peraturan Pemerintah Nomor 37 Tahun 2002 tentang Hak dan Kewajiban Kapal dan Pesawat Udara Asing dalam Melaksanakan Hak Lintas Alur Laut Kepulauan melalui Alur Laut Kepulauan yang Ditetapkan, dan Peraturan Pemerintah Nomor 38 Tahun 2002 tentang Daftar Koordinat Geografis TititkTiitik Garis Pangkal Kepulauan Indonesia.

Zona Tambahan (Contingous Waters), setiap negara pantai yang laut teritorialnya melebihi 12 mil laut berarti ia juga akan mempunyai zona tambahan (contiguous zone) yang mempunyai peranan penting dalam keamanan dan pembangunan ekonominya. Hak dan Kewajiban Indonesia serta Status saat ini, di zona tambahan tersebut adalah 
mencegah pelanggaran peraturan perundangundangan tentang bea cukai, fiskal, imigrasi, dan sanitasi yang dapat merugikan Indonesia, serta menegakkan hukumnya, sehingga para pelaku pelanggaran tersebut dapat diadili.

Zona Ekonomi Eksklusif (ZEE), perkembangan zona ekonomi eksklusif (exclusive economic zone) mencerminkan kebiasaan internasional (international customs) yang diterima menjadi hukum kebiasaan internasional (customary international law) karena sudah terpenuhi dua syarat penting, yaitu praktik negara-negara (state practice) dan opinio juris sive necessitatis. Zona ekonomi eksklusif bagi negara berkembang seperti Indonesia adalah vital karena di dalamnya terdapat kekayaan sumber daya alam hayati dan nonhayati, sehingga mempuyai peranan sangat penting bagi pembangunan ekonomi bangsa dan negara. Hak dan Kewajiban Indonesia atas ZEE adalah hak-hak, jurisdiksi, dan kewajiban yang sudah terikat oleh Konvensi Hukum Laut 1982 dengan ratifikasi UU No. 17 Tahun 1985. Hak-hak, jurisdiksi, dan kewajiban Indonesia pada Konvensi tersebut sudah ditentukan oleh Pasal 56.

Landas Kontinen (Continental Shelf), di atur oleh Pasal 76 s/d Pasal 85 Konvensi Hukum Laut (Unclos) 1982 yang di dalamnya terdapat pengertian landas kontinen, hak Negara pantai di landas kontinen, penetapan batas landas kontinen oleh setiap negara, pembuatan peta dan koordinat geografis dan menyampaikan ke Sekretaris Jenderal PBB. Hak dan Kewajiban Indonesia serta Status saat ini terhadap Landas Kontinen (Continental Shelf), adalah Indonesia mempunyak hak eksplorasi dan eksploitasi kekayaan sumber daya alam di landas kontinen sebagaimana diatur oleh Pasal 77 Konvensi Hukum Laut 1982, tetapi di samping itu Indonesia mempunyai kewajiban untuk menetapkan batas terluar landas kontinen sejauh 350 mil dan menyampaikan kepada Komisi Landas Kontinen (Commission on the Limits of the Continental Shelf) yang selanjutnya diatur oleh Lampiran (Annex) II Konvensi Hukum Laut 1982. Penentapan batas-batas landas kontinen baik sejauh 200 mil maupun 350 mil tersebut wajib disampaikan salinannya kepada Sekretaris Jenderal PBB yang di dalamnya memuat informasi yang relevan. Indonesia juga harus melakukan negosiasi penetapan batas-batas landas kontinen dengan negara tetangga.

Laut Lepas (High Seas), yaitu semua bagian laut yang tidak termasuk zona ekonomi eksklusif, laut territorial atau perairan pedalaman suatu negara dan perairan kepulauan dalam Negara kepulauan (Pasal 86 Unclos 1982). Hak dan Kewajiban Indonesia serta Status saat ini di laut lepas (high seas) adalah berhak menangkap ikan di laut lepas, namun semua negara juga berkewajiban untuk mengambil tindakan-tindakan conservation dan bekerjasama dalam melestarikan dan mengatur sumber-sumber kehidupan hayati di laut lepas (Pasal 117, Pasal 118 Unclos)), jika perlu ikut serta dalam organisasi-organisasi internasional regional dan sub-regional seperti Internasional Sea Bed Authority (ISBA), International Maritime Organization (IMO) Regional Fisheries Management Organization. Di bidang perikanan, UndangUndang Nomor 31 Tahun 2004 tentang Perikanan harus lebih dioptimalkan karena di dalamnya mengatur penangkapan ikan sampai di zona ekonomi eksklusif bahkan sampai laut lepas.

Secara keseluruhan, hak dan kewajiban Negara Indonesia berdasar Konvensi Hukum Laut 1982 (United Nations Convention on the Law of the Sea) setelah meratifikasi dengan UU No. 17 Tahun 1985 dapat dijabarkan dalam tabel berikut ini : 


\begin{tabular}{|c|c|c|c|c|}
\hline No & $\begin{array}{c}\text { Konvensi Hukum Laut } \\
\text { Internasional } \\
\text { (UNCLOS) } 1982\end{array}$ & Hak-Hak Indonesia & Kewajiban Indonesia & $\begin{array}{c}\text { Keterangan/ Reko- } \\
\text { mendasi }\end{array}$ \\
\hline 1 & $\begin{array}{l}\text { Pasal 1: } \\
\text { (4)"Pollution of the } \\
\text { marine environment" } \\
\text { (5) dumping }\end{array}$ & $\begin{array}{l}\text { Hak berdaulat eks- } \\
\text { ploitasi lingkungan } \\
\text { laut (Pasal 193). }\end{array}$ & $\begin{array}{l}\text { Wajib melindungi dan } \\
\text { Melestarikan lingkungan } \\
\text { laut (Pasal 192). }\end{array}$ & $\begin{array}{l}\text { - Perlu ditetapkan batas } \\
\text { wilayah perairan peda- } \\
\text { laman. } \\
\text { - Sudah ada di PP. No. } 19 \\
\text { Tahun1999 sebaiknya } \\
\text { ditingkatkan ke UU. } \\
\text { - Dumping tunduk pada } \\
\text { LDC } 1972 \text {. }\end{array}$ \\
\hline 2 & $\begin{array}{l}\text { Pasal 2-32: } \\
\text { tentang rejim laut teri- } \\
\text { torial sejauh } 12 \text { mil dari } \\
\text { garis pang-kal (lebar } \\
\text { laut terito-rial, garis } \\
\text { pangkal normal/lurus, } \\
\text { batas laut teriorial, peta } \\
\text { dan daftar koodinat geo- } \\
\text { grafis, hak lintas damai } \\
\text { bagi kapal asing di laut } \\
\text { teritorial. }\end{array}$ & kedaulatan & $\begin{array}{l}\text { - Wajib membuat peta } \\
\text { dan koordinat geo- } \\
\text { grafis dan menyam- } \\
\text { paikannya salinannya } \\
\text { kpd Sekjen PBB (Pasal } \\
\text { 16). } \\
\text { Wajib menghormati } \\
\text { hak lintas damai kapal } \\
\text { asing di laut teritorial } \\
\text { Indonesi }\end{array}$ & $\begin{array}{l}\text { - Rejim laut teritorial } \\
\text { sudah implementing } \\
\text { legislation dgn UU No } \\
6 \text { Tahun } 1996 \text { dan PP } \\
36, \text { PP 37, dan PP } 38 \text { th } \\
2002 \text { namun perlu dikaji } \\
\text { kembali. } \\
\text { - Pasal } 16 \text { belum dilaku- } \\
\text { kan Indonesia. } \\
\text { - Harus menyampaikan ke } \\
\text { Sekjen PBB pada tahun } \\
\text { 2009. } \\
\text { - Meninjau kembali garis } \\
\text { pangkal laut wilayah. }\end{array}$ \\
\hline 3 & $\begin{array}{l}\text { Pasal 33: } \\
\text { Rejim zona tambahan } \\
\text { (contiguous zone) sejauh } \\
24 \text { mil dari garis pang- } \\
\text { kal }\end{array}$ & $\begin{array}{l}\text { Hak jurisdiksi penga- } \\
\text { wasan untuk mence- } \\
\text { gah pelangaran pera- } \\
\text { turan bea cukai, fis- } \\
\text { kal, imigrasi, saniter, } \\
\text { dan menghukum pe- } \\
\text { lakunya }\end{array}$ & $\begin{array}{l}\text { Tidak ada kewajiban } \\
\text { karena ini hak jurisdiksi } \\
\text { kontrol dan menghu- } \\
\text { kumnya, tapi kalau ada } \\
\text { pelanggaran wajib dipro- } \\
\text { ses karena untuk kepen- } \\
\text { tingan Indonesia }\end{array}$ & $\begin{array}{l}\text { - Perlu diatur mengenai } \\
\text { Zona tambahan. } \\
\text { - Sebaiknya diadopsi oleh } \\
\text { uu terkait, misal : bea } \\
\text { cukai, imigrasi, dll. }\end{array}$ \\
\hline 4 & $\begin{array}{l}\text { Pasal 34-45: } \\
\text { Hak lintas transit, alur } \\
\text { laut, skema pemisah } \\
\text { dalam selat internasional }\end{array}$ & $\begin{array}{l}\text { - Hak kedaulatan pe- } \\
\text { nuh atas selat atau } \\
\text { jurisdiksi } \\
\text { bergantung pada } \\
\text { status selat. } \\
\text { Hak membangun } \\
\text { ke-amanan yang } \\
\text { andal }\end{array}$ & $\begin{array}{l}\text { Wajib menghormati } \\
\text { hak lintas transit. } \\
\text { - Wajib memberi tahu } \\
\text { bahaya. } \\
\text { - Tidak boleh ada sus- } \\
\text { pensi } \\
\text {-Keselamatan pelaya-ran }\end{array}$ & $\begin{array}{l}\text { - Sudah diatur oleh Pasal } \\
20 \text { UU No.6/1996. } \\
\text { - Memanfaatkan peluang } \\
\text { hak lintas damai dan } \\
\text { transit dgn membangun } \\
\text { pelabuhan tingkat inter- } \\
\text { nasional. } \\
\text { - UU No. 21/1992 yang } \\
\text { dirubah menjadi UU } 17 \\
\text { Tahun 2008. }\end{array}$ \\
\hline 5 & $\begin{array}{l}\text { Pasal 46-53: } \\
\text { Rejim negara kepulauan } \\
\text { (garis pangkal kepulau- } \\
\text { an, hak lintas damai,hak } \\
\text { ALKI) }\end{array}$ & $\begin{array}{l}\text { Perairan kepulauan } \\
\text { berada dalam kedau- } \\
\text { latan penuh Indonesia }\end{array}$ & $\begin{array}{l}\text { - Wajib menghormati } \\
\text { perairan internasional } \\
\text { yang sudah ada dengan } \\
\text { negara lain. } \\
\text { - Wajib menghormati } \\
\text { hak tradisional } \\
\text { penangkap-an ikan } \\
\text { negara lain. } \\
\text { - Wajib menghomati ka- } \\
\text { bel bawah laut negara } \\
\text { lain }\end{array}$ & $\begin{array}{l}\text { - Sudah diatur oleh UU } \\
\text { No.6/ } 1996 \text { dan ketiga } \\
\text { PP : PP No.36/37/38 } \\
\text { tahun 2002. } \\
\text { - Indonesia bukan hanya } \\
\text { negara kepulauan, tapi } \\
\text { harus jadi negara } \\
\text { kelautan (SDA dan } \\
\text { pela-yaran harus } \\
\text { dioptimal-kan) }\end{array}$ \\
\hline 6 & Pasal 55-75: & Hak berdaulat dan ju- & - Dapat memberikan hak & - Sudah diimplementing \\
\hline
\end{tabular}




\begin{tabular}{|c|c|c|c|c|}
\hline No & $\begin{array}{c}\text { Konvensi Hukum Laut } \\
\text { Internasional } \\
\text { (UNCLOS) } 1982\end{array}$ & Hak-Hak Indonesia & Kewajiban Indonesia & $\begin{array}{c}\text { Keterangan/ Reko- } \\
\text { mendasi }\end{array}$ \\
\hline & $\begin{array}{l}\text { Rejim zona ekonomi } \\
\text { eksklusif sejauh } 200 \text { mil } \\
\text { dari garis pangkal }\end{array}$ & $\begin{array}{l}\text { risdiksi negara, bukan } \\
\text { berada dalam kedau- } \\
\text { latan Indonesia }\end{array}$ & $\begin{array}{l}\text { akses pada negara lain } \\
\text { untuk memanfaatkan } \\
\text { sumber daya hayati. } \\
\text { - Wajib konservasi atas } \\
\text { sumber daya hayati } \\
\text { dan nonhayati. } \\
\text { - Penegakan hukum atas } \\
\text { pelanggaran di ZEE } \\
\text { Indonesia. } \\
\text { - Menegakkan hukum } \\
\text { krn banyak kapal asing } \\
\text { berorasi } \\
\text { mengambil keuntung- } \\
\text { an. } \\
\text { Penyelesaian batas- } \\
\text { batas ZEE Indonesia } \\
\text { dengan negara lain. } \\
\text { - Wajib membuat peta } \\
\text { dan koordinat geogra- } \\
\text { fis dan menyampai - } \\
\text { kan salinannya ke } \\
\text { Sekjen PBB. }\end{array}$ & $\begin{array}{l}\text { legislation : UU No. } \\
\text { 6/1996. } \\
\text { - Sudah ada PP No. } \\
\text { 36/37/38. } \\
\text { - Mengadakan perjanjian } \\
\text { batas ZEEdengan } \\
\text { negara tetangga. } \\
\text { - Membuat peta dan } \\
\text { koodinat geografis. } \\
\text { - Sudah ada implementing } \\
\text { legislation : UU No. } \\
\text { 5/1983 ttg ZEE } \\
\text { Indonesia. } \\
\text { - Wajib menyampaikan ke } \\
\text { Sekjen PBB. } \\
\text {-Mengumumkan pemba- } \\
\text { ngunan dan letak } \\
\text { pulau-pulau buatan, } \\
\text { instalasi dan bangunan } \\
\text { lainnya. }\end{array}$ \\
\hline 7 & $\begin{array}{l}\text { Pasal 76-85: } \\
\text { Pengaturan tentang } \\
\text { Landas Kontinen }\end{array}$ & $\begin{array}{l}\text { Hak berdaulat dan } \\
\text { jurisdiksi negara }\end{array}$ & $\begin{array}{l}\text { - Wajib membuat uu } \\
\text { karena UU sebelum- } \\
\text { nya masih mengacu } \\
\text { pada Konvensi Jene- } \\
\text { wa } 1958 . \\
\text { Menetapkan batas- } \\
\text { batas NKRI dengan } \\
\text { negara lain. } \\
\text { - Membuat peta dan } \\
\text { Koordinat geografis. } \\
\text { Wajib melaporkan } \\
\text { salinannya ke Sekjen } \\
\text { PBB }\end{array}$ & $\begin{array}{l}\text { - Berdayakan sdm dan } \\
\text { teknologi. } \\
\text { - Buat UU baru tentang } \\
\text { Landas Kontinen kare- } \\
\text { na UU No.1/ } 1973 \\
\text { masih mengacu pada } \\
\text { Konvensi Jenewa } \\
\text { 1958. } \\
\text { Melaporkan Landas } \\
\text { Kontinen Indonesia ke } \\
\text { PBB pada tahun 2009. }\end{array}$ \\
\hline 8 & $\begin{array}{l}\text { Pasal 86-120: } \\
\text { Nasional Indonesia High } \\
\text { Seas (laut lepas) }\end{array}$ & $\begin{array}{l}\text { Rejim internasional : } \\
\text {-Tidak ada } \\
\text { kedaulatan Negara } \\
\text { manapun. } \\
\text { - Ada } 6 \text { kebebasan } \\
\text { laut lepas untuk } \\
\text { tujuan damai. } \\
\text { •Hak melakukan pe- } \\
\text { ngejaran terhadap } \\
\text { kapal yang diduga } \\
\text { melanggar hukum } \\
\text { nasional Indonesia. }\end{array}$ & $\begin{array}{l}\text { Kewajiban negara } \\
\text { bende-ra: } \\
\text { - Melaksanakan juris- } \\
\text { diksi dan mengenda- } \\
\text { likan kapal yang me- } \\
\text { ngibarkan bendera- } \\
\text { nya. } \\
\text { - Wajib membantu kece- } \\
\text { lakaan / bahaya di laut } \\
\text { lepas. } \\
\text { - Wajib memberantas } \\
\text { perompakan, perda- } \\
\text { gangan narkotika, per- } \\
\text { dagangan budak. }\end{array}$ & $\begin{array}{l}\text { - } \text { Sudah cukup diatur oleh } \\
\text { UU No. } 31 / 2004 \\
\text { tentang Peri-kanan } \\
\text { bahwa laut lepas dapat } \\
\text { dijadikan } \quad \text { wilayah } \\
\text { penang-kapan ikan } \\
\text { karena setiap negara } \\
\text { mempunyai kebe-basan } \\
\text { menangkap ikan. } \\
\text { Sebaiknya Indonesia } \\
\text { ber-dayakan terlebih } \\
\text { dahulu hukum } \\
\text { nasionalnya : UU No. } \\
\text { 6/1996 dan ketiga PP- } \\
\text { nya, UU No. 5/1983 ttg } \\
\text { ZEE Indo-nesia. }\end{array}$ \\
\hline
\end{tabular}




\begin{tabular}{|c|c|c|c|}
\hline No & $\begin{array}{l}\text { Konvensi Hukum Laut } \\
\text { Internasional } \\
\text { (UNCLOS) } 1982\end{array}$ & Hak-Hak Indonesia & Kewajiban Indonesia \\
\hline
\end{tabular}

9 Pasal 121: Rejim Pulau

10 Pasal 133-191: Kawasan (Area)

11 Pasal 192-237: Perlindungan dan Pelestarian Lingkungan Laut
Hak kedaulatan negara mempertahankan seluruh pulau Indonesia terutama pulau terluar

\section{Kewajiban \\ bende-ra : \\ - Melaksanakan juris- diksi dan mengendali- kan kapal yang me- ngibarkan bendera- nya. \\ - Wajib membantu kece- lakaan / bahaya di laut lepas. \\ - Wajib memberantas perompakan, perda- gangan narkotika, per-dagangan budak.}

Rejim internasional : Wajib berperan serta

- common heritage of sebagai negara berkemmankind.

- Pengelolaan kekaya-an di Kawasan bera-da pada Badan Otorita Intern/ ISA.

- Hak berdaulat (Pasal 193) atas kekayaan sumber daya alam di laut. bang dan bekerja sama dengan perusahaan.

- Wajib melindungi dan melestarikan lingkungan laut.

- Mencegah, mengurangi, dan mengendalikan pencemaran laut.

- Wajib bekerja sama regional dan global.

- Membuat UU tentang pencegahan, pengurangan, dan pengendalian pencemaran laut

- Penegakan hukum oleh negara pantai, negara bendera, negara pelabuhan.
Keterangan/ Rekomendasi

-Perkuat Indonesia dengan armada kapal ikan.

- Ikut berperan aktif dalam lembaga-lembaga regi-onal maupun interna-sional

- Sudah cukup diatur oleh UU No. 31/2004 tentang Peri-kanan bahwa laut lepas dapat dijadikan wilayah penangkapan ikan karena setiap nega-ra mempunyai kebebas-an menangkap ikan.

- Sebaiknya Indonesia berdayakan terlebih dahulu hukum nasionalnya : UU No. 6/1996 dan ketiga PP-nya, UU No. 5/1983 ttg ZEE Indo-nesia.

- Perkuat Indonesia dengan armada kapal ikan.

- Ikut berperan aktif dalam lembaga-lembaga regi-onal maupun internasi-onal.

Ikut berperan aktif dan kerjasama dengan lembaga-lembaga regional maupun internasional di bidang kelautan

- Koordinasi dengan KLH yang telah membuat peraturan perundangundangan tentang lingkungan hidup dan pengendalian pencemaran laut.

- Perlu dibuat uu tentang pencegahan dan pengen-dalian pencemaran laut, menggantikan PP No. 19 Tahun 1999

Keterangan / Reko- 


\begin{tabular}{|c|c|c|c|c|}
\hline No & $\begin{array}{c}\text { Konvensi Hukum Laut } \\
\text { Internasional } \\
\text { (UNCLOS) } 1982\end{array}$ & Hak-Hak Indonesia & Kewajiban Indonesia & $\begin{array}{c}\text { Keterangan/ Reko- } \\
\text { mendasi }\end{array}$ \\
\hline No & $\begin{array}{c}\text { Internasional } \\
\text { (UNCLOS) } 1982\end{array}$ & & & mendasi \\
\hline 12 & $\begin{array}{l}\text { Pasal 238 - 265: } \\
\text { Riset Ilmiah Kelautan }\end{array}$ & $\begin{array}{l}\text { - Hak berdaulat / } \\
\text { eksklusif untuk } \\
\text { riset ilmiah } \\
\text { kelautan untuk } \\
\text { tujuan damai di } \\
\text { landas kontinen dan } \\
\text { laut. } \\
\text { - Hak negara tak ber- } \\
\text { pantai dan tidak } \\
\text { beruntung secara } \\
\text { geografis untuk } \\
\text { riset ilmiah kelaut- } \\
\text { an. }\end{array}$ & $\begin{array}{l}\text { - Wajib bekerja sama } \\
\text { dengan sesama } \\
\text { negara dan organisasi } \\
\text { inter-nasional. } \\
\text { - Wajib membangun } \\
\text { pusat-pusat nasional } \\
\text { riset ilmiah kelautan. }\end{array}$ & $\begin{array}{l}\text { - Riset ilmiah kelautan } \\
\text { mempunyai peranan } \\
\text { penting bagi pemba- } \\
\text { ngunan nasional. } \\
\text { - Mengembangkan budaya } \\
\text { riset ilmiah kelautan. } \\
\text { Perlu pengaturan } \\
\text { menge-nai riset ilmiah } \\
\text { kelautan di Indonesia. } \\
\text { Berperan aktif dalam } \\
\text { lembaga teknologi kela- } \\
\text { utan internasional. }\end{array}$ \\
\hline 13 & $\begin{array}{l}\text { Pasal 266-278: } \\
\text { Pengembangan dan Alih } \\
\text { Teknologi Kelautan }\end{array}$ & $\begin{array}{l}\text { - Hak mengembang- } \\
\text { kan teknologi kela- } \\
\text { utan; } \\
\text { Hak kerja sama } \\
\text { dengan pemilik tek- } \\
\text { nologi kelautan. }\end{array}$ & $\begin{array}{l}\text { - Wajib kerja sama inter- } \\
\text { nasional dan regional. } \\
\text { Wajib membangun } \\
\text { pusat-pusat riset nasi- } \\
\text { onal untuk pengem- } \\
\text { bangan teknologi ke- } \\
\text { lautan, apalagi Indo- } \\
\text { nesia adalah negara } \\
\text { kepulauan. }\end{array}$ & $\begin{array}{l}\text { - Indonesia harus mempu- } \\
\text { nyai kebijakan yang } \\
\text { mengatur tentang alih } \\
\text { teknologi kelautan. } \\
\text { - Budayakan dan perkuat } \\
\text { pengembangan dan alih } \\
\text { tek-nologi kelautan, } \\
\text { Indonesia harus menjadi } \\
\text { negara mandiri dalam } \\
\text { teknologi kelautan. }\end{array}$ \\
\hline 14 & $\begin{array}{l}\text { Pasal 279-299: } \\
\text { Penyelesaian sengketa } \\
\text { bidang hukum laut : } \\
\text { ITLOS, ICJ, Arbitrase, } \\
\text { dan Arbitrase Khusus. }\end{array}$ & $\begin{array}{l}\text { Setiap negara mem- } \\
\text { punyai hak untuk me- } \\
\text { nyelesaikan sengketa } \\
\text { bidang hukum laut } \\
\text { secara bilateral dan } \\
\text { keempat forum tsb. }\end{array}$ & $\begin{array}{l}\text { Setiap negara wajib } \\
\text { menyelesaikan seng-keta } \\
\text { di bidang hukum laut } \\
\text { secara damai dari mulai } \\
\text { negosiasi sampai ICJ. }\end{array}$ & $\begin{array}{l}\text { Indonesia harus bekerja } \\
\text { keras menjaga dan melak- } \\
\text { sanakan kedaulatan dan } \\
\text { jurisdiksi negara atas ke- } \\
\text { kayaan di laut. }\end{array}$ \\
\hline 15 & $\begin{array}{l}\text { Pasal } 303 \text { dan } 149 \text { : } \\
\text { Benda-benda purbakala } \\
\text { dan bersejarah ditemu- } \\
\text { kan di laut. }\end{array}$ & $\begin{array}{l}\text { Hak pemilik benda- } \\
\text { benda berharga terse- } \\
\text { but dan negara } \\
\text { pantai. }\end{array}$ & $\begin{array}{l}\text { Setiap negara wajib me- } \\
\text { lindungi benda-benda tsb } \\
\text { dan bekerja sama dalam } \\
\text { penyelesaiannya. }\end{array}$ & $\begin{array}{l}\text { Perlu koordanasi yang } \\
\text { baik dalam persoalan pe- } \\
\text { nemuan benda-benda ber- } \\
\text { harga tsb. Perlu dikaji apa } \\
\text { perlu uu tentang ini, dan } \\
\text { memperhatikan Konvensi } \\
\text { UNESCO } 2001 \text {. }\end{array}$ \\
\hline 16 & $\begin{array}{l}\text { Pasal 312: } \\
\text { Amandemen Konvensi } \\
\text { Hukum Laut } 1982\end{array}$ & $\begin{array}{l}\text { Indonesia punyak hak } \\
\text { untuk mengusulkan } \\
\text { perubahan atas Kon- } \\
\text { vensi ini untuk } \\
\text { kepen-tingan bangsa } \\
\text { dan negara. }\end{array}$ & $\begin{array}{l}\text { Indonesia wajib melak- } \\
\text { sanakan semua keten- } \\
\text { tuan Konvensi Hukum } \\
\text { Laut } 1982 \text { dalam kon- } \\
\text { teks kepentingan bangsa } \\
\text { dan negara }\end{array}$ & $\begin{array}{l}\text { Indonesia harus melak- } \\
\text { sanakan semua ketentuan } \\
\text { Konvensi Hukum Laut } \\
1982 \text { dalam konteks ke- } \\
\text { pentingan bangsa dan ne- } \\
\text { gara. }\end{array}$ \\
\hline
\end{tabular}




\section{Mewujudkan Konsep Poros Maritim Dunia Sesuai Ketentuan UNCLOS 1982}

Fakta paradigma pembangunan dengan adanya ketimpangan pembangunan di sektor laut dan daratan serta keterpurukan ekonomi, pemerintahan Presiden Joko Widodo telah menata laut demi kemakmuran bangsa, dengan mengusung tema kemaritiman dengan "Poros Maritim Dunia" dan "Tol Laut". Bangsa Indonesia memang sudah seharusnya menata dan membangun laut khususnya kemaritiman menjadi modal pembangunan menuju kemakmuran bangsa. Mewujudkan hal tersebut masih akan menemui berbagai persoalan, mulai dari persoalan ego sektoral dalam upaya penegakan hukum kemaritiman hingga persoalan sarana dan prasarana yang merupakan pemenuhan infrstruktur yang memadai di Indonesia.

\section{a. Penegakan Hukum Kemaritiman di Indonesia.}

Hukum Maritim Internasional yang sudah disepakati Indonesia sejak tahun 1974 (SOLAS 1974) telah mengatur penegakan hukum kemaritiman yang tertuang dalam :

1). Bab V Peraturan 15 Konvensi Internasional tentang Keselamatan Jiwa di Laut (SOLAS 1974) mengenai kewajiban negara penandatangan untuk membentuk organisasi Pengawal Pantai (Coast Guard) atau Pengawal Laut dan Pantai (Sea and Coast Guard).

2). Ketentuan Internasional tentang Keamanan Kapal dan Fasilitas PelabuhanTahun 2002 atau International Ships and Port Facilities Security Code 2002 (ISPS Code 2002) mengenai kewajiban negara peserta untuk menetapkan otoritas nasional dan otoritas lokal yang bertanggungjawab atas keselamatan dan keamanan maritim.

3). Pasal 217, pasal 218 dan pasal 220 Konvensi Perserikatan Bangsa- bangsa tentang Hukum Laut (UNCLOS III, 1982) mengenai penegakan hukum oleh Negara Bendera (Flag State), oleh Negara
Pelabuhan (Port State), dan oleh Negara Pantai (Coastal State).

Indonesia selama ini menganut sistem multi-agen yang merupakan sistem kelembagaan, dimana terdapat lebih dari 1(satu) institusi/lembaga yang berinteraksi secara bersama-sama untuk mencapai atau untuk menyelesaikan masalah yang sama. Pada tahun 2014, melalui Perpres Nomor178 Tahun 2014 telah terbentuk Badan Keamanan Laut (Bakamla) yang sebelumnya bernama Badan Koordinasi Keamanan Laut (Bakorkamla). Ferber dan Gutknecht berpendapat bahwa agen-agen penegakan hukum di laut merupakan suatu entitas otonom yang berperilaku individual. Sifat interaksi multi-agen tersebut timbul karena: pertama, sistem organisasi yang heterogen. Masing-masing institusi mempunyai struktur organisasi tersendiri; kedua, perbedaan budaya dan sistem kerja antar organisasi. Meski berada dalam satu platform atau satu cakupan bidang, masing-masing organisasi dikembangkan dengan gaya yang berbeda sesuai dengan visi masing-masing organisasi.(J. Ferber; O. Gutknecht, 1998)

Secara teroritis, aktor utama yang memiliki kewenangan dalam kemaritiman untuk melakukan kontrol atas arus lintas maritim adalah Polisi Perairan (Polair), Petugas Imigrasi, dan Petugas Bea Cukai. Polair, tugas utamanya adalah pencegahan dan penindakan terhadap aktifitas arus lintas barang dan orang yang bersifat illegal, pendeteksian ancaman keamanan, serta pengontrolan terhadap orang dan barang di titik awal hingga tujuan, penyelidikan dan penyidikan tindak kejahatan atau pun peristiwa kecelakaan/insiden.

Petugas Imigrasi bertanggung jawab untuk melakukan kontrol persyaratan dan pelarangan masuk barang dan orang, menjamin legalitas dari dokumen perjalanan, mengidentifikasi dan menginvestigasi tindak kejahatan, dan membantu orang-orang yang membutuhkan pertolongan. Petugas bea cukai pada dasarnya bertugas untuk mengatur arus 
barang dan jasa. Fungsinya adalah memfasilitasi perdagangan sesuai persyaratan yang ditentukan tentang keluar masuk barang, memastikan pelaksanaan bea dan pajak masuk, serta melindungi kesehatan arus lintas manusia, hewan dan binatang.

Di Indonesia pada kenyataannya terdapat 12 (dua belas) instansi yang melakukan penegakan hukum dan peraturan tentang laut secara bersama-sama. Lembaga-lembaga tersebut mempunyai landasan hukum masingmasing yang isinya hampir bersinggungan. Pemerintahan Presiden Joko Widodo, merubah sistem kelembagaan multi agent menjadi single agent untuk penegakan hukum di laut Indonesia, yaitu dengan merubah Bakorkamla menjadi Bakamla.(Reveron, 2016)(Dewi Santoso; Fadhillah Nafisah, 2017) ${ }^{1}$ Fungsi kontrol dalam kemaritiman memang perlu dilaksanakan melalui pendekatan integratif antar aktor yang berwenang. Hal ini dengan mempertimbangkan bentang laut seharusnya terdapat mekanisme koordinatif pembagian kerja antara patroli laut, pengamanan keluar masuk arus manusia dan barang di sejumlah pelabuhan melalui kontrol dokumen perjalanan dan kebijakan bea serta dukungan sistem pengawasan (surveillance). Namun, sentimen sektoral dan minimnya dukungan anggaran seringkali menjadi hambatan untuk pengembangan fungsi koordinatif seperti sudah disebutkan di atas, sehingga aktor yang

${ }^{1}$ Reveron, Derek dalam hal ini menyatakan "However, to safeguard the country's maritime territories, Indonesian government has recently established a new Maritime Security Agency named Indonesian Maritime Security Board (Badan Keamanan Laut Republik Indonesia, 'BAKAMLA'), to better coordinate joint sea patrols and rescue on Indonesia's territorial water. Its mission is to foster the realization of national and international maritime security which is able to guard the and safety in the territorial sea and jurisdiction of Indonesia; therefore, BAKAMLA shall act as guards to the 'World's Maritime Axis'. Protecting territorial sovereignty forms top priority of Indonesian foreign policy”. seharusnya bertanggung jawab melakukan fungsi kontrol melalui kerja koordinatif, akhirnya berjalan sendiri-sendiri dengan semangat ego sektoral.

\section{b. Menuju Poros Maritim Dunia}

Pengakuan internasional terhadap keberadaan wilayah perairan Indonesia meliputi 4 hal yaitu Perairan Nusantara, Laut Teritorial, batas Landas Kontinen, dan batas Zona Ekonomi Eksklusif (ZEE). Dalam konteks ekonomi, Indonesia belum mampu memanfaatkan selat strategis seperti Selat Malaka dan 3 (tiga) Alur Laut Kepulauan Indonesia $(\mathrm{ALKI})^{2}$ sebagai sumber pendapatan negara, melalui pengembangan berbagai aktivitas ekonomi. Dalam pengembangan negara maritim, Indonesia harus memiliki visi "outward looking" didasarkan pada peraturan internasional yang dimungkinkan untuk mendapatkan sumberdaya alam laut secara global maupun mengembangkan kekuatan armada laut nasional untuk dapat menguasai pelayaran internasional dengan menciptakan daya saing, sehingga kapal-kapal berbendera Indonesia menguasai pelayaran internasional dan memiliki kekuatan laut (sea power) yang unggul. ${ }^{3}$

Implementasi mengenai gagasan tol laut dan poros maritim diwujudkan dengan menyiapkan infrastruktur pelabuhan dan penyeberangan. Infrastruktur pelabuhan dan penyeberangan yang memadai dan terkelola dengan manajemen yang efisien, maka nantinya arus barang dan jasa serta orang akan lebih baik. Langkah-langkah yang akan ditempuh untuk mewujudkan gagasan

\footnotetext{
${ }^{2}$ ALKI I melintasi Laut Cina Selatan, Selat Karimata, Laut Jawa, Selat Sunda.

ALKI II melintasi Laut Sulawesi, Selat Makassar, Laut Flores, Selat Lombok.

ALKI III Melintas Samudra Pasifik, Laut Maluku, Laut Seram, Laut Banda, Selat Ombai dan Laut Sawu.

${ }^{3}$ Sea power bukan hanya diartikan sebagai pemaknaan kekuatan militer (Angkatan Laut), tetapi juga kekuatan lain seperti armada angkutan pelayaran sipil.
} 
tersebut, Kementerian Perencanaan Pembangunan Nasional (PPN)/ Bappenas telah mendesain konsep tol laut yang dicetuskan Presiden Joko Widodo, dengan 24 pelabuhan. Pelabuhan sebanyak itu terbagi atas pelabuhan yang menjadi hubungan internasional, pelabuhan utama dan pelabuhan pengumpul.(Geoffrey Till, 2013)

\section{Simpulan dan Saran}

1. Simpulan

a. Aturan hukum laut yang diakui secara internasional menjadi sangat penting, sebagai aturan yang dapat diacu bersama khususnya oleh negara-negara yang telah meratifikasinya dalam menetapkan kebijakan kelautan. Hak dan kewajiban Indonesia dalam melaksanakan Unclos 1982 telah terimplementasikan ke dalam bentuk peraturan perundang-undangan nasional.

b. Indonesia sebagai negara kepulauan terbesar di dunia, kondisi geografis yang strategis, kaya akan sumberdaya alam, namun semuanya masih belum dapat dimanfaatkan secara optimal demi kemakmuran bangsa. Banyak faktor yang menyebabkan hal tersebut, mulai dari kesalahan paradigma pembangunan hingga carut marutnya upaya penegakan hukum kemaritiman.

c. Kendala pemenuhan intrastruktur yang memadai dalam kemaritiman merupakan kendala utama yang harus diselesaikan pemerintah, karena keberadaan infrastruktur akan memungkinkan

${ }^{4} 24$ pelabuhan itu, antara lain: Pelabuhan Banda Aceh, Belawan, Kuala Tanjung, Dumai, Batam, Padang, Pangkal Pinang, Pelabuhan Panjang. Selanjutnya, Pelabuhan Tanjung Priok, Cilacap, Tanjung Perak, Lombok, Kupang, Pontianak, Palangkaraya, Banjarmasin, Maloy, Makassar, Bitung, Halmahera, Ambon, Sorong, Merauke dan Jayapura. Tiga pelabuhan yaitu, Kuala Tanjung, Bitung dan Sorong yang akan dibangun baru, sedangkan sisanya hanya perluasan atau pengembangan. pelayanan yang lebih baik dalam upaya menuju sebagai poros maritim dunia.

2. Saran

a. Pengembangan paradigma dan dukungan studi kelayakan yang memadai, harus mampu meyakinkan pengambil kebijakan agar benar-benar berpihak pada rezim pembangunan yang berorientasi pada potensi kelautan dan perikanan. Perhitungan tentang prospek kontribusinya terhadap perekonomian maritim dan kesejahteraan rakyat, harus menjadi perhatian pengambil kebijakan.

b. Pembenahan sistem penegakan hukum melalui penguatan dan koordinasi antar lembaga yang berwenang di laut sangat diperlukan dan ditekankan, sehingga akan sangat menunjang bagi terciptanya kepastian dan keselarasan dalam penegakan hukum.

\section{DAFTAR PUSTAKA}

Boer Mauna. (n.d.). Perumusuan Kebijakan Sumber Daya Maritim.

Boer Mauna. (2005). Hukum Internasional: Pengertian Peranan Dan Fungsi Dalam Era Dinamika Global. Bandung: Alumni.

Brian W. Hogwood; Lewis. A. Gun. (1984). Policy Analysis For The Real Word. London: Oxford University Press.

Dewi Santoso; Fadhillah Nafisah. (2017). Indonesia's Global Maritime Axis Doctrine: Security Concerns and Recommendations. Jurnal Hubungan Internasiona, 10(2), 91.

Geoffrey Till. (2013). Seapower: A Guide for the Twenty-First Century. New York: Routledge.

Hadi, S. (1980). Metodologi Riset. Yayasan Penerbit Fakultas Psikologi UGM.

J. Ferber; O. Gutknecht. (1998). A MetaModel for The Analysis and Design of Organizations in Multi-Agent Systems. In Proceedings of Third International Conference on Multi-Agent System (ICMA 98). IEEE Computer Society. 
Kawilarang, R. R. . (n.d.). Warisan Besar Menlu Hassan Wirajuda. Retrieved from http://www.viva.co.id/ berita/dunia/98969-warisan-besar-menluhassan- wirajuda2009

Kurniawati, D. E. (n.d.). PENDEKATAN INTERMESTIK DALAM PROSES PERUBAHAN KEBIJAKAN: SEBUAH REVIEW METODOLOGIS. Retrieved from

https://media.neliti.com/media/publicatio ns/131965-ID-pendekatan-intermestikdalam-proses-peru.pdf\%0D

Melda Kamil Ariadno. (2018). Ambalat
Miliki Siapa? Retrieved from http://www.topix.com/forum/world/indon esia

Reveron, D. (2016). Maritime Security Deficits and InternationalCooperation: Illegal Fishing, Piracy, and Maritime Security Deficits in Southeast Asia. Georgetown Journal of Asian Affairs, 3(1), 36-41.

Wahab. (2005). Analisis Kebijakan: Dari Formulasi ke Implementasi Kebijakan Negara. Jakarta: Bumi Aksara.

Winarno, B. (2007). Kebijakan Publik Teori dan Proses. Yogyakarta: MedPress. 